\title{
OCTABROMODIPHENYL ETHER - PORPHYROGENICITY AFTER REPEATED ADMINISTRATION TO RATS
}

\author{
ELŻBIETA BRUCHAJZER, BARBARA FRYDRYCH, and JADWIGA A. SZYMAŃSKA
}

\author{
Medical University of Łódź, Łódź, Poland \\ Department of Toxicology
}

\begin{abstract}
Objectives: Octabromodiphenyl ether (OctaBDE) is a flame retardant which has been withdrawn from common use due to its negative effect on the environment. The literature data regarding its toxicity addresses its effect on liver function, the endocrine and reproductive systems, as well as its developmental toxicology aspects. The aim of this study was to investigate the effect of repeated administration of OctaBDE on heme biosynthesis in rats. Materials and Methods: The study was performed on female Wistar rats. OctaBDE was administered intragastrically at four different doses $(2,8,40 \mathrm{or} 200 \mathrm{mg} / \mathrm{kg} / \mathrm{day})$ for 7, 14, 21 or 28 days. The following measures of heme synthesis disturbance were used: urinary excretion of porphyrins, liver concentration of porphyrins, the activity of delta-aminolevulinate synthase (ALA-S) and delta-aminolevulinate dehydratase (ALA-D) in the liver. Results: After 28 days of exposure, lower ALA-S and ALA-D activity was observed in the liver. Additionally, increased concentrations of high carboxylated porphyrins (octa- and heptacarboxyporphyrins) were found in the liver: from 2- to 10 -fold after the $2 \mathrm{mg} / \mathrm{kg} /$ day doses and from 4- to 14 -fold after the 8-200 mg/kg/day doses. The porphyrogenic effect of OctaBDE was also evidenced by augmented, dose-dependent and exposure time-dependent, concentrations of total porphyrins in urine (2-7.5-fold increase) and their urinary excretion (2-9-fold increase). Tetracarboxyporphyrins predominated in the urine; their concentrations increased 2.5-10 fold. Conclusions: The study revealed that repeated exposure to OctaBDE affects heme biosynthesis and the levels of porphyrins. The lowest effective level which induced changes in porphyrin concentration was $2 \mathrm{mg} / \mathrm{kg} / \mathrm{day}$.
\end{abstract}

Key words:

Octabromodiphenyl ether (OctaBDE), Porphyrins, Rat, Repeated administration

\section{INTRODUCTION}

Octabromodiphenyl ether (OctaBDE) is a compound that for many years was commonly used as a flame retardant. From among three of popular polybromodiphenyl ethers (PBDEs) (penta-, octa- and decabromodiphenyl ethers) approximately $15 \%$ was represented by OctaBDE. In the early 1990's, worldwide production of OctaBDE reached 6000 tonnes/year but by 1999, it fell to about 1800 tonnes, 450 tonnes being produced in the European
Union. OctaBDE has been used in combination with antimony trioxide as a flame retardant in the housings of electric and electronic equipment, mainly in plastic such as arylonitrile butadiene styrene (ABS), but also in high impact polystyrene (HIPS), polybutylene terephthalate (PBT) and polyamides. Typically, $12-15 \%$ of the weight of the final product will consist of OctaBDE [1].

Due to its harmful effect to the environment, OctaBDE is classified as a POP (Persistent Organic Pollutant) and

This study was funded by the Medical University of Łódź (Join Project No. 503/3-045-01/503-01).

Received: October 25, 2011. Accepted: February 3, 2012.

Address reprint request to E. Bruchajzer, Department of Toxicology, Medical University of Łódź, Muszyńskiego 1, 90-151 Łódź, Poland (e-mail: elzbieta.bruchajzer@umed.lodz.pl). 
the use and production of this compound was banned in 2004 [2,3]. OctaBDE could be found throughout the environment, from bottom sediments and sewage sludge to the tissues of aquatic animals. The concentrations of OctaBDE in those locations were, however, lower than the concentrations of the remaining ethers: PentaBDE and DecaBDE $[1,4,5]$. Based on its octanol-water partition coefficients ( $\log$ Kow $=8.35-8.9$ ) octabromodiphenyl ether could be expected to be bioaccumulative. However, experimental results indicate that the OctaBDE does not bioconcentrate, possibly due to its large particle size preventing it crossing cell walls [1].

Human exposure to OctaBDE is mainly associated with its intake with food, and it has been found in milk, seafood and fish $[1,6]$. Some congeners of OctaBDE have been found in the serum, adipose tissue and in breast milk of women [1,7-10]. However, occupational exposure, such as inhalation during the use and dismantling of electric and electronic appliances, during the use of computer hardware, and environmental exposure through indoor air and dust can be an additional source of human exposure to OctaBDE [9,11-16].

Brominated flame retardants are characterized by low acute toxicity. The median lethal dose $\left(\mathrm{LD}_{50}\right)$ of these compounds after intragastrical administration to rats considerably exceeded $5000 \mathrm{mg} / \mathrm{kg}$ of body weight, implying that hexabromobenzene (HBB), tetrabromobisphenol-A (TBBP-A), PentaBDE (pentabromodiphenyl ether) and OctaBDE should not be classified as toxic substances. However, toxic effects have been seen to occur after changing the type of exposure, such as that occurring with lower doses and longer exposure times. Studies in this area so far have focussed on the effect of repeated administration of polybrominated diphenyl ethers on thyroid gland disorders, functional changes in the liver and immunotoxicity, as well as the effect on reproductive system and developmental toxicity. Less information are accessible about these toxic effects from studies concerning the administration of OctaBDE [1,10,17-20].

From the literature, it is known that many brominated flame retardants (polybrominated biphenyls (PBB), HBB and TBBP-A) disturb the transformations of porphyrins [21-24]. Among the PBDEs, a porphyrogenic effect was also observed after repeated administration of PentaBDE $[1,25,26]$. However, information concerning any similar effects of OctaBDE was not found.

The aim of this study was to investigate the porphyrogenic effect of OctaBDE after repeated intragastrical administration of the compound to rats. This effect was evaluated by measuring the activity of two enzymes from the heme synthesis pathway in the liver, ALA-S and ALA-D, as well as the concentrations of porphyrins with varying degrees of carboxylation in rat liver and urine. The daily excretion and content of particular porphyrins in urine was also analyzed. Moreover, the multidirectional toxic effect of PBDEs causes that it seems reasonable to search for new, more sensitive biomarkers evaluating the effects of OctaBDE.

\section{MATERIAL AND METHODS}

\section{Animals}

Female Wistar rats of 190-230 g body weight from the breeding colony of the Medical University of Lódź were used in the experiment. The animals were fed a standard pelletized "Murigran" diet, with tap water accessible ad libitum. The rats were divided into groups of 4-5 animals each.

\section{Chemical}

The administered OctaBDE was a mixture of polybrominated ethers: octa- $(65.7 \%)$; hepta- $(14.8 \%)$; hexa- $(1.7 \%)$; nona- and deca- (17.8\%, trace amount). This mixture was synthesized by the Department of Radiation Chemistry of the Technical University of Łódź. 


\section{Animal treatment}

OctaBDE, dissolved in sunflower oil, was administered intragastrically (i.g.). Two control groups were used in each experiment, "pure controls" (rats not given any compound) and "oil controls" (rats given the medium, i.g. $0.5 \mathrm{~cm}^{3}$ of sunflower oil per $200 \mathrm{~g}$ of body mass). OctaBDE was administered i.g. to the rats at doses of 2, 8, 40 or $200 \mathrm{mg} / \mathrm{kg} /$ day. After 7, 14, 21 and 28 days, 24-h urine collections were obtained from rats.

After 7, 14, 21 and 28 days of OctaBDE administration, the animals were killed under ether anaesthesia by puncture of the left ventricle of the heart. The urinary and hepatic concentrations of porphyrins were determined.

\section{Biochemical analysis}

Preparation of liver

Fifty percent homogenates of liver tissue in phosphorus buffer, $\mathrm{pH}=6.8$, were prepared in an ice bath. The isolation of porphyrins from tissue was performed according to Luo and Lim [27]. The resultant homogenate was shaken for 30 seconds with dimethyl sulfoxide (DMSO) 1:1. Following this, it was centrifuged for $5 \mathrm{~min}$ at $2500 \mathrm{~g}$, and the resultant supernatant was applied into the ultra performance liquid chromatography (UPLC) column.

\section{Determinations of porphyrins by high performance liquid chromatography}

The method was a modified version of the procedure described by Lim and Peters [28]. The analyses were carried out using an Acquity UltraPerformance LC $^{\circledR}$ liquid chromatograph. The analytical parameters were as follows: Acquity UPLC ${ }^{\circledR}$ BEH C-18 $1.7 \mu \mathrm{m}$ column $(10 \mathrm{~cm} \times 2.1 \mathrm{~mm})$. Detector: spectrofluorometer (measurements were carried out at $\mathrm{Ex}=404 \mathrm{~nm}$; $\mathrm{Em}=618 \mathrm{~nm}$ ). Liquid phase: $\mathrm{A}-10 \%$ acetonitrile solution $(\mathrm{v} / \mathrm{v})$ in $1 \mathrm{M}$ solution of ammonium acetate, $\mathrm{pH}=5.16 ; \mathrm{B}-10 \%$ acetonitrile solution $(\mathrm{v} / \mathrm{v})$ in methanol. Liquid flow through the column was as follows: between 0 and $5.4 \mathrm{~min}-100 \%$ phase A, between 5.4 and $9.5 \mathrm{~min}-35 \%$ phase $\mathrm{A}$ and $65 \%$ phase $\mathrm{B}$, between 9.5 and $10 \mathrm{~min}-100 \%$ phase A. Flow: $0.35 \mathrm{~cm}^{3} / \mathrm{min}$. Volume of injection: $10 \mu$ l. Calibration curves were prepared from tetra-, penta-, hexa-, hepta- and octa-carboxyporphyrins. A mixture of octa-, hepta-, hexa-, penta- and tetracarboxy-porphyrins was used as a porphyrin standard (Porphyrin Acid Chromatographic Marker Kit obtained from Porphyrin Products, Logan, USA).

The following measures of heme synthesis disturbance were used: urinary excretion of porphyrins, liver concentration of porphyrins, the activity of delta-aminolevulinate synthase (ALA-S; EC 2.3.1.37) and deltaaminolevulinate dehydratase (ALA-D; EC 4.2.1.24) in the liver. ALA-S was estimated according to Sassa and Granick [29]; the method is based on a colorimetric measurement of pyrroles ensuing in the reaction of deltaaminolevulinic acid with acetoacetone at $\mathrm{pH}=4.9$. The modified Ehrlich reagent reacts with $\alpha$-pyroles, forming a coloured complex. ALA-D activity, however, was assayed according to Berlin and Schaller [30], as modified by Schlick et al. [31]. This method is based on colorimetric measurement of porphobilinogen (PBG) ensuing from the 5-aminolevulinic acid (ALA) under the influence of ALA-D.

\section{Ethics}

The experiment was performed with the permission of the Local Ethical Committee for Experimentation on Animals (Resolution No. 17/LB457/2009). The Polish regulations concerning the protection of animals were observed [32].

\section{Statistics}

The statistical analysis was performed using the SYSTAT for Windows software package. The significance of differences for selected parameters was set with Tukey's test after checking for homogeneity of variance with Bartlett's test. 


\section{RESULTS}

The assessment of the effect of repeated administration of OctaBDE was based on selected biological parameters (change in weight of animals), biochemical parameters (changes of ALA-S and ALA-D activity in liver) and the concentrations of porphyrins with different degrees of carboxylation (octa-, hepta-, hexa-, penta- and tetracarboxyporphyrins) in liver tissue and urine.

A reduction of body weight gain during the experiment was observed in the laboratory animals after administration of OctaBDE, one of the early symptoms caused by a xenobiotic (Table 1). After the lowest dose of the compound $(2 \mathrm{mg} / \mathrm{kg} /$ day) a slight decline in body weight gain was observed; however, more pronounced statistically significant changes were noted after OctaBDE administration at doses of 40 and $200 \mathrm{mg} / \mathrm{kg} /$ day. After 28 days of exposure, the body weight of rats receiving $40 \mathrm{mg} / \mathrm{kg} /$ day OctaBDE decreased by $12 \%$ as compared to the control group, and the body weight of the rats receiving $200 \mathrm{mg} / \mathrm{kg} /$ day decreased by about $20 \%$.

Throughout the experiment, the changes in the monitored parameters were compared with the results obtained in control groups. Two basic control groups, "pure controls" and "oil controls" were used in the study. The results obtained in the pure controls of individual sections did not differ statistically from each other; therefore for statistical analysis, their results were combined in one pooled control group. However, this approach was not applied to "oil controls" owing to the different number of doses $(7,14,21$ or 28) of the medium (oil).

To assess the porphyrogenic effect of OctaBDE, the activities of ALA-S and ALA-D (the enzymes that take part in the initial stage of heme synthesis) were measured. After repeated administration of OctaBDE at 2 and $8 \mathrm{mg} / \mathrm{kg} /$ day, fluctuations in ALA-S activity were observed in the liver (Table 2). After 28 days of exposure, a significant decrease in ALA-S activity was observed: by about $35 \%$ after the $200 \mathrm{mg} / \mathrm{kg} /$ day dose.

Even greater changes were observed in ALA-D activity in the liver (Table 2). After a temporary increase in activity after 7 days of OctaBDE administration at doses of 2 and $8 \mathrm{mg} / \mathrm{kg} /$ day, ALA-D activity was seen to decrease. This effect after 14-21 days of exposure was dependent on the administered dose of the compound. After

Table 1. Changes in body mass after repeated, intragastrical administration of octabromodiphenyl ether (OctaBDE)

\begin{tabular}{lcccc}
\hline & \multicolumn{5}{c}{ Changes in body mass depending on time of exposure } \\
M \pm SD \\
Doses of OctaBDE
\end{tabular}

Body weight of animals at the start of experiment $=100 \%$.

$\mathrm{N}$ - number animals in the group.

$\mathrm{M}$ - mean, SD - standard deviation.

$\mathrm{a}$ - significantly different from pure control animals, $\alpha=0.05 ; \mathrm{b}$ - significantly different from oil control animals, $\alpha=0.05 ; \mathrm{c}-$ significantly different from the group of rats given OctaBDE at a dose of $2 \mathrm{mg} / \mathrm{kg} / \mathrm{day}, \alpha=0.05 ; \mathrm{d}-$ significantly different from the group of rats given OctaBDE at a dose of $8 \mathrm{mg} / \mathrm{kg} /$ day, $\alpha=0.05$; e - significantly different from the group of rats given OctaBDE at a dose of $40 \mathrm{mg} / \mathrm{kg} / \mathrm{day}, \alpha=0.05$. 
Table 2. ALA-S and ALA-D activity in rat liver after repeated, intragastrical administration of OctaBDE

\begin{tabular}{|c|c|c|c|c|}
\hline \multirow[t]{2}{*}{ Doses of OctaBDE } & \multicolumn{4}{|c|}{$\begin{array}{c}\text { Days of exposure } \\
\mathrm{M} \pm \mathrm{SD}\end{array}$} \\
\hline & 7 & 14 & 21 & 28 \\
\hline \multicolumn{5}{|l|}{$\begin{array}{l}\text { ALA-S activity in } \\
\text { liver [nmol ALA/ } \\
60 \mathrm{~min} / \mathrm{g} \text { of tissue] }\end{array}$} \\
\hline pure control $(\mathrm{N}=16)$ & \multicolumn{4}{|c|}{$21.2 \pm 3.29$} \\
\hline oil control $(\mathrm{N}=4)$ & $16.5 \pm 1.91$ & $27.7 \pm 1.46^{\mathrm{a}}$ & $22.1 \pm 3.23$ & $24.7 \pm 1.92$ \\
\hline $2 \mathrm{mg} / \mathrm{kg} /$ day $(\mathrm{N}=5)$ & $20.6 \pm 2.85$ & $25.7 \pm 2.58$ & $24.5 \pm 2.58$ & $22.5 \pm 2.81$ \\
\hline $8 \mathrm{mg} / \mathrm{kg} / \mathrm{day}(\mathrm{N}=5)$ & $23.0 \pm 3.90^{\mathrm{b}}$ & $29.5 \pm 2.32^{\mathrm{a}}$ & $22.2 \pm 1.76$ & $23.4 \pm 1.04$ \\
\hline $40 \mathrm{mg} / \mathrm{kg} /$ day $(\mathrm{N}=5)$ & $19.3 \pm 1.99$ & $23.8 \pm 3.96$ & $19.8 \pm 4.08$ & $19.3 \pm 0.69^{\mathrm{bd}}$ \\
\hline $200 \mathrm{mg} / \mathrm{kg} /$ day $(\mathrm{N}=5)$ & $22.1 \pm 1.53^{\mathrm{b}}$ & $20.9 \pm 3.52^{\mathrm{bd}}$ & $11.0 \pm 2.10^{\text {abcde }}$ & $13.8 \pm 1.15^{\text {abcde }}$ \\
\hline \multicolumn{5}{|l|}{$\begin{array}{l}\text { ALA-D activity in } \\
\text { liver [ } \mu \mathrm{mol} \mathrm{PBG} / \mathrm{g} \text { of } \\
\text { tissue] }\end{array}$} \\
\hline pure control $(\mathrm{N}=16)$ & \multicolumn{4}{|c|}{$20.1 \pm 2.79$} \\
\hline oil control $(\mathrm{N}=4)$ & $28.6 \pm 2.24^{\mathrm{a}}$ & $16.5 \pm 1.62$ & $20.4 \pm 0.51$ & $22.8 \pm 2.35$ \\
\hline $2 \mathrm{mg} / \mathrm{kg} /$ day $(\mathrm{N}=5)$ & $25.4 \pm 1.74^{\mathrm{a}}$ & $18.9 \pm 1.38$ & $19.3 \pm 0.98$ & $18.4 \pm 1.10^{\mathrm{b}}$ \\
\hline $8 \mathrm{mg} / \mathrm{kg} / \mathrm{day}(\mathrm{N}=5)$ & $26.6 \pm 2.42$ & $17.3 \pm 2.40$ & $18.9 \pm 1.33$ & $19.6 \pm 2.71$ \\
\hline $40 \mathrm{mg} / \mathrm{kg} /$ day $(\mathrm{N}=5)$ & $19.8 \pm 1.92^{\mathrm{bcd}}$ & $13.8 \pm 2.25^{\mathrm{ac}}$ & $13.8 \pm 1.92^{\text {abcd }}$ & $11.4 \pm 1.06^{\mathrm{abcd}}$ \\
\hline $200 \mathrm{mg} / \mathrm{kg} /$ day $(\mathrm{N}=5)$ & $16.3 \pm 2.74^{\mathrm{bcd}}$ & $8.4 \pm 0.76^{\text {abcde }}$ & $8.0 \pm 1.18^{\text {abcde }}$ & $8.1 \pm 1.07^{\text {abcde }}$ \\
\hline
\end{tabular}

ALA-S - delta-aminolevulinate synthase; ALA-D - delta-aminolevilinate dehydratase; OctaBDE - octabromodiphenyl ether. Other abbreviations as in Table 1.

two highest doses (40 and $200 \mathrm{mg} / \mathrm{kg} /$ day) ALA-D activity in liver decreased by about $60 \%$.

In addition, to evaluate the porphyrogenic effect of OctaBDE, five porphyrins with varying degrees of carboxylation were analysed. In pure controls, concentrations of the high carboxylated porphyrins (octa- and heptacarboxyporphyrins) were approximately $95 \%$ of the total porphyrins. The results from rats exposed to OctaBDE revealed that almost $100 \%$ of prophyrins present in liver were octa- and hepta-carboxyporphyrins. Other porphyrins (hexa-, penta- and tetracarboxyporphyrins) occurred most often in amounts less than $1 \%$ of total porphyrin. Such low concentrations did not affect the overall picture of the changes and, therefore, the results shown in Figure 1 are the sum of the high carboxylated porphyrins: octa- and heptacarboxyporphyrins. An analysis of this data indicates that repeated administration of OctaBDE to rats caused an increase of porphyrin concentration in liver tissue. After 7 and 14 days, the levels of the high carboxylated porphyrins in the 8 and $40 \mathrm{mg} / \mathrm{kg} /$ day groups were 4-6 times higher than in the pure control, and after the dose of $200 \mathrm{mg} / \mathrm{kg} /$ day, the increase was about 7 times higher. After 28 days of exposure, significant changes were observed; the concentrations of high carboxylated porphyrins increased 10 -fold in the $2 \mathrm{mg} / \mathrm{kg} /$ day group, and 14-fold in the $8 \mathrm{mg} / \mathrm{kg} /$ day group. After the higher doses (40 and $200 \mathrm{mg} / \mathrm{kg} /$ day), a 4.5 -fold increase in the level of porphyrins in liver was noted (Figure 1).

Of the high carboxylated porphyrins (octa- and heptacarboxyporphyrins) in the liver of control rats, 


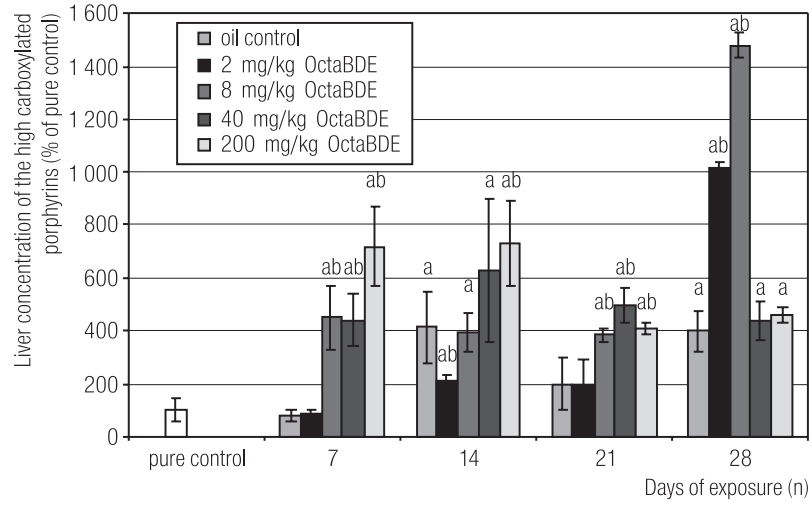

a - significantly different from pure control animals, $\alpha=0.05$.

$\mathrm{b}$ - significantly different from oil control animals, $\alpha=0.05$.

The results are expressed as $\mathrm{M} \pm \mathrm{SD}$.

Fig. 1. Liver concentrations of the sum of the high carboxylated porphyrins (octa- and heptacarboxyporphyrins) after repeated, intragastrical administration of octabromodiphenyl ether (OctaBDE)

approximately $30 \%$ were heptacarboxyporphyrins, and $70 \%$ were octa-carboxyporphyrins. After administration of OctaBDE, the octacarboxyporphyrin share increased to $80-85 \%$.

After repeated administration of OctaBDE, increased total porphyrin concentrations were observed in the urine (Figure 2). The highest concentrations (about 6-7-fold increase) were noted at doses of 40 and $200 \mathrm{mg} / \mathrm{kg} /$ day after 21 and 28 days' administration, while after a shorter period (7 and 14 days), an approximately 3 -fold increase was observed in total urinary porphyrin concentration. After the lowest dose ( $2 \mathrm{mg} / \mathrm{kg} /$ day $)$, a statistically significant increase of total prophyrin concentration was observed after 21 and 28 days of exposure.

Octa-, tetra- and hepta- carboxyporphyrins, (37\%, 33\% and $23 \%$ of total porphyrins, respectively) were found to dominate in the urinary prophyrin profile of rats from the control group (Table 3). Penta- and hexa- carboxyporphyrin content was only about $1.6 \%$ and $5.7 \%$, respectively. Repeated administration of OctaBDE caused an exposuretime-dependent decrease of octacarboxyporphyrins (uroporphyrins) down to as few as about $12 \%$ after 28 days,

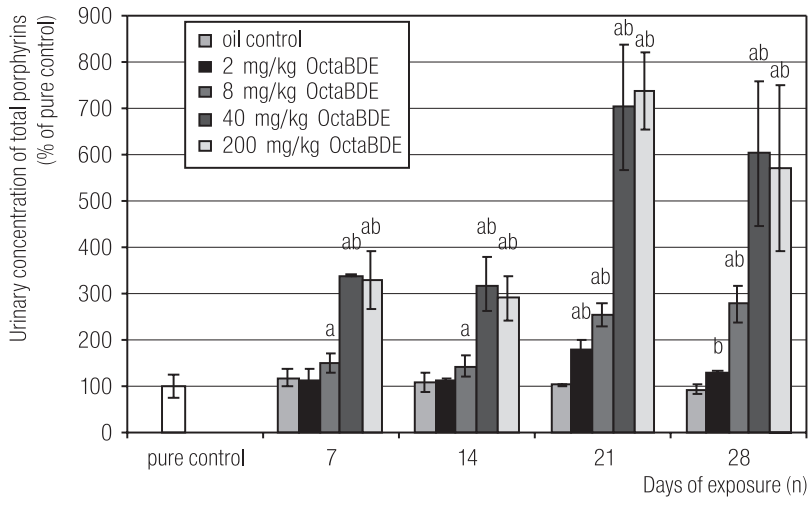

Abbreviations as in Figure 1.

Fig. 2. Urinary concentrations of total porphyrins after repeated, intragastrical administration of octabromodiphenyl ether (OctaBDE)

and increase of tetracarboxyporphyrins (coprocarboxyporphyrins) to approximately $50 \%$.

After recording 24-hour diuresis and taking urine density measurements, the results were presented as daily urinary excretion of porphyrins (Figure 3 ). These results indicate a significant effect of repeated OctaBDE administration on total porphyrin excretion in the urine of rats. This was particularly evident after the administration of OctaBDE at the two highest doses. After 21 days of exposure, a 4-fold increase was observed after $40 \mathrm{mg} / \mathrm{kg} / \mathrm{day}$, and a 9-fold increase after $200 \mathrm{mg} / \mathrm{kg} /$ day. Similar values were noted after 28 days, with the levels increasing 6-7-fold. The lowest dose causing a statistically significant increase of porphyrin excretion in the urine was $8 \mathrm{mg} / \mathrm{kg} /$ day. No such effects were noted for the lowest dose of $2 \mathrm{mg} / \mathrm{kg} /$ day used in this study (Figure 3).

An assessment of porphyrogenic activity can be also performed by analysing the ratio of coproporphyrins to uroporphyrins (tetracarboxyporphyrins to octacarboxyporphyrins) excreted with urine. After 7 days of exposure to OctaBDE at a dose of $200 \mathrm{mg} / \mathrm{kg} / \mathrm{day}$, an approximately 2.5 -fold increase in the ratio was noted. The increase (1.5-3-fold) was found after doses of 8-200 mg/kg/day administered 14 times. After 21 and 28 days of exposure at 
Table 3. Urinary levels of porphyrins (\% of control animals) after repeated, intragastrical administration of OctaBDE

\begin{tabular}{|c|c|c|c|c|}
\hline \multirow[t]{2}{*}{ Doses of OctaBDE } & \multicolumn{4}{|c|}{$\begin{array}{l}\text { Urinary levels of porphyrins depending on time of exposure } \\
\qquad \mathrm{M} \pm \mathrm{SD} \\
(\%)\end{array}$} \\
\hline & 7 days & 14 days & 21 days & 28 days \\
\hline \multicolumn{5}{|l|}{$\begin{array}{l}\text { Octacarboxyporphyrins } \\
\text { (uroporphyrins) }\end{array}$} \\
\hline pure control $(\mathrm{N}=16)$ & \multicolumn{4}{|c|}{$100 \pm 25$} \\
\hline oil control $(\mathrm{N}=4)$ & $132.8 \pm 31.9$ & $123.3 \pm 44.4$ & $95.7 \pm 5.8$ & $93.1 \pm 13.4$ \\
\hline $2 \mathrm{mg} / \mathrm{kg} /$ day $(\mathrm{N}=5)$ & $122.8 \pm 2.15$ & $113.8 \pm 10.8$ & $142.7 \pm 28.9^{\mathrm{b}}$ & $106 \pm 12.9$ \\
\hline $8 \mathrm{mg} / \mathrm{kg} /$ day $(\mathrm{N}=5)$ & $109.5 \pm 31$ & $111.2 \pm 27.6$ & $150.4 \pm 23.5^{\mathrm{ab}}$ & $185.3 \pm 27.1^{\mathrm{abc}}$ \\
\hline $40 \mathrm{mg} / \mathrm{kg} /$ day $(\mathrm{N}=5)$ & $237.5 \pm 11.6^{\mathrm{abcd}}$ & $164.2 \pm 43.1^{1 \mathrm{ab}}$ & $357.3 \pm 83.6^{\text {abcd }}$ & $237.1 \pm 63.4^{\mathrm{abc}}$ \\
\hline $200 \mathrm{mg} / \mathrm{kg} /$ day $(\mathrm{N}=5)$ & $167.7 \pm 14.7^{\text {abcde }}$ & $142.7 \pm 16.4^{\mathrm{a}}$ & $509.9 \pm 50^{\text {abcde }}$ & $200.4 \pm 63.8^{\mathrm{abc}}$ \\
\hline $\begin{array}{l}\text { Heptacarboxyporphyrins } \\
\text { pure control }(\mathrm{N}=16)\end{array}$ & \multicolumn{4}{|c|}{$100 \pm 22.9$} \\
\hline oil control $(\mathrm{N}=4)$ & $103.5 \pm 20.1$ & $134.7 \pm 27.1$ & $100.7 \pm 13.2$ & $120.8 \pm 7.6$ \\
\hline $2 \mathrm{mg} / \mathrm{kg} /$ day $(\mathrm{N}=5)$ & $103.5 \pm 22.8$ & $113.2 \pm 15.3$ & $121.5 \pm 13.2$ & $149.3 \pm 20.8^{\mathrm{a}}$ \\
\hline $8 \mathrm{mg} / \mathrm{kg} /$ day $(\mathrm{N}=5)$ & $256.3 \pm 52.8^{\text {abcd }}$ & $133.3 \pm 21.5$ & $374.3 \pm 126.4^{\mathrm{abc}}$ & $450.7 \pm 29.9^{\text {abcd }}$ \\
\hline $40 \mathrm{mg} / \mathrm{kg} /$ day $(\mathrm{N}=5)$ & $736.1 \pm 28.5^{\mathrm{abcd}}$ & $747 \pm 295^{\text {abcd }}$ & $1067 \pm 70.1^{\mathrm{abcd}}$ & $827 \pm 167.4^{\text {abcd }}$ \\
\hline $200 \mathrm{mg} / \mathrm{kg} /$ day $(\mathrm{N}=5)$ & $430.6 \pm 75.7^{\text {abcde }}$ & $346 \pm 51.4^{\text {abcde }}$ & $1244 \pm 173.6^{\mathrm{abcd}}$ & $896 \pm 150.7^{\text {abcd }}$ \\
\hline \multicolumn{5}{|l|}{$\begin{array}{l}\text { Hexacarboxyporphyrins } \\
\text { pure control }(\mathrm{N}=16)\end{array}$} \\
\hline oil control $(\mathrm{N}=4)$ & $70 \pm 30$ & $70 \pm 2$ & $50 \pm 4^{\mathrm{a}}$ & $70 \pm 30$ \\
\hline $2 \mathrm{mg} / \mathrm{kg} /$ day $(\mathrm{N}=5)$ & $200 \pm 40^{\mathrm{a}}$ & $110 \pm 5^{\mathrm{b}}$ & $130 \pm 20^{\mathrm{b}}$ & $140 \pm 30^{b}$ \\
\hline $8 \mathrm{mg} / \mathrm{kg} /$ day $(\mathrm{N}=5)$ & $240 \pm 80^{\mathrm{a}}$ & $130 \pm 10^{\mathrm{bc}}$ & $160 \pm 40^{b}$ & $170 \pm 40^{\mathrm{b}}$ \\
\hline $40 \mathrm{mg} / \mathrm{kg} /$ day $(\mathrm{N}=5)$ & $230 \pm 50^{\mathrm{a}}$ & $170 \pm 40^{\mathrm{bc}}$ & $230 \pm 40^{\mathrm{abc}}$ & $150 \pm 50^{\mathrm{b}}$ \\
\hline $200 \mathrm{mg} / \mathrm{kg} /$ day $(\mathrm{N}=5)$ & $140 \pm 6^{\text {abcde }}$ & $170 \pm 20^{\mathrm{abcd}}$ & $290 \pm 40^{\mathrm{abcd}}$ & $190 \pm 40^{\mathrm{ab}}$ \\
\hline $\begin{array}{r}\text { Pentacarboxyporphyrins } \\
\text { pure control }(\mathrm{N}=16)\end{array}$ & \multicolumn{4}{|c|}{$100 \pm 22.2$} \\
\hline oil control $(\mathrm{N}=4)$ & $88.9 \pm 0.6$ & $86.1 \pm 11.1$ & $88.9 \pm 16.7$ & $86.1 \pm 11.1$ \\
\hline $2 \mathrm{mg} / \mathrm{kg} /$ day $(\mathrm{N}=5)$ & $88.9 \pm 16.7$ & $88.9 \pm 2.8$ & $161.1 \pm 30.6^{\mathrm{ab}}$ & $127.8 \pm 22.2^{b}$ \\
\hline $8 \mathrm{mg} / \mathrm{kg} / \mathrm{day}(\mathrm{N}=5)$ & $116.7 \pm 5.6^{\mathrm{bc}}$ & $116.7 \pm 19.5^{\mathrm{bc}}$ & $125.0 \pm 19.4$ & $147.2 \pm 11.1^{\mathrm{ab}}$ \\
\hline $40 \mathrm{mg} / \mathrm{kg} /$ day $(\mathrm{N}=5)$ & $169.4 \pm 5.6^{\text {abcd }}$ & $152.8 \pm 25.0^{\mathrm{abc}}$ & $380.6 \pm 22.5^{\mathrm{abd}}$ & $383.3 \pm 88.9^{\text {abcd }}$ \\
\hline $200 \mathrm{mg} / \mathrm{kg} /$ day $(\mathrm{N}=5)$ & $197.2 \pm 38.9^{\mathrm{abcd}}$ & $208.3 \pm 13.9^{\text {abcde }}$ & $416.7 \pm 116.7^{7 \mathrm{abcd}}$ & $280.6 \pm 116.7^{\mathrm{abcd}}$ \\
\hline \multicolumn{5}{|l|}{$\begin{array}{l}\text { Tetracarboxyporphyrins } \\
\text { (coproporphyrins) }\end{array}$} \\
\hline pure control $(\mathrm{N}=16)$ & \multicolumn{4}{|c|}{$100 \pm 13$} \\
\hline oil control $(\mathrm{N}=4)$ & $130.4 \pm 5.8^{\mathrm{a}}$ & $92.3 \pm 42$ & $128.0 \pm 3.9^{\mathrm{a}}$ & $88.4 \pm 9.2$ \\
\hline $2 \mathrm{mg} / \mathrm{kg} /$ day $(\mathrm{N}=5)$ & $126.1 \pm 8.2^{\mathrm{a}}$ & $128.0 \pm 3.4^{\mathrm{a}}$ & $294.7 \pm 25.6^{\mathrm{ab}}$ & $152.2 \pm 23.7^{\mathrm{ab}}$ \\
\hline $8 \mathrm{mg} / \mathrm{kg} /$ day $(\mathrm{N}=5)$ & $138.2 \pm 2.4^{\mathrm{a}}$ & $210.1 \pm 25.6^{\mathrm{abc}}$ & $345.4 \pm 15.5^{\mathrm{abc}}$ & $320.8 \pm 79.7$ abc \\
\hline $40 \mathrm{mg} / \mathrm{kg} /$ day $(\mathrm{N}=5)$ & $252.7 \pm 3.4^{\mathrm{abcd}}$ & $270.5 \pm 23.2^{\mathrm{abcd}}$ & $1006 \pm 311.6^{\mathrm{abcd}}$ & $791.3 \pm 370.5^{\text {abcd }}$ \\
\hline $200 \mathrm{mg} / \mathrm{kg} /$ day $(\mathrm{N}=5)$ & $505.8 \pm 243.5^{\text {abcde }}$ & $476.3 \pm 99.0^{\mathrm{abcde}}$ & $807.2 \pm 80.2^{\mathrm{abcd}}$ & $899.5 \pm 407.7^{\text {abcd }}$ \\
\hline
\end{tabular}

Concentrations of porphyrins in pure control $\left(\mathrm{ng} / \mathrm{cm}^{3}\right)$ : octacarboxyporphyrins $-23.2 \pm 5.8$; heptacarboxyporphyrins $-14.4 \pm 3.3$; hexacarboxyporphyrins $-1.0 \pm 0.3$; pentacarboxyporphyrins $-3.6 \pm 0.8$; tetracarboxyporphyrins $-20.7 \pm 2.7$; total porphyrins $-65.4 \pm 15.8$.

Abbreviations as in Table 1. 


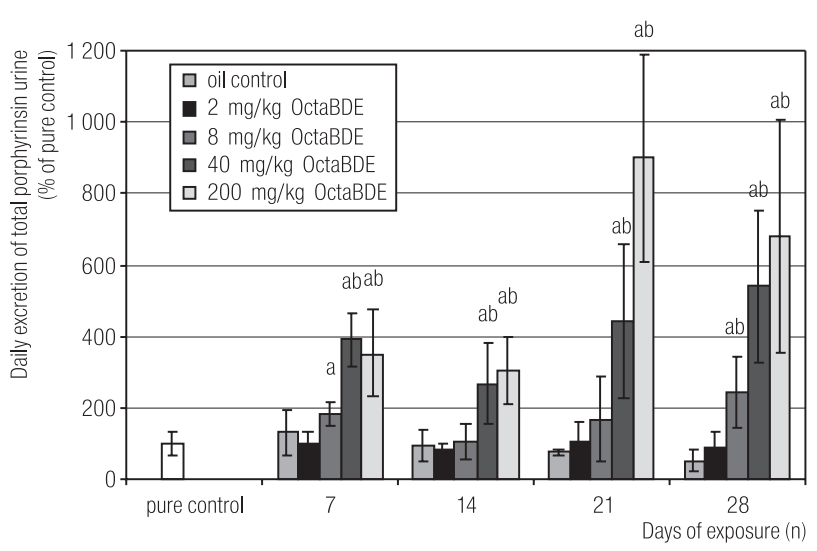

Abbreviations as in Figure 1.

Pure control group: $433.8 \pm 148.14$ ng/day.

Fig. 3. Daily excretion of total porphyrins in urine after repeated, intragastrical administration of octabromodiphenyl ether (OctaBDE)

all doses, these changes were statistically significant. The observed 1.3-4-fold increase in the ratio of excreted urinary copro-/uroporphyrins after 28 days was dependent on the administered dose of OctaBDE (data not shown). Similar effect was noted after PentaBDE [25].

\section{DISCUSSION}

Disturbances in heme biosynthesis often are associated with changes in the activity of the enzymes catalyzing the process and can result in the occurrence of porphyria, which may be congenital or acquired. Most heme synthesis occurs in the bone marrow, while 15-20\% occurs in the liver. The most important factors affecting the porphyrogenic activity of xenobiotics are the changes in the levels of heme precursors, such as porphyrins, in the liver. In heme synthesis, two enzymes (ALA-S and ALA-D) are of basic significance. ALA-S is an enzyme that controls heme biosynthesis in mammal livers and is involved in the synthesis of delta-aminolevulinic acid (ALA) through the condensation of glycine and succinyl-CoA (after decarboxylation). The ALA molecules then combine to form porphobilonogen (PBG): a reaction catalyzed by dehydratase ALA
(ALA-D), also known as PBG synthase (porfobilinogen synthase). Condensation of four molecules of PBG creates porphyrins [33-36].

Due to clinical symptoms such as abdominal pain, skin lesions, atypical polyneuropathy, and mental disorders suggesting psychosis, the diagnosis of porphyria is very difficult. In humans, the diagnosis is based on, among other things, the quantitative determination of porphyrins in urine (usually uroporphyrins and coproporphyrins) as well as their precursors: ALA and PBG $[34,35]$. In laboratory animals, the diagnostic procedure can be extended to include determining the activity of ALA-S, ALA-D, synthase uroporphyrinogen (URO-S) and dacarboxylase uroporphyrinogen (URO-D) in the liver. URO-D catalyses the conversion of uroporphyrinogen into coproporphyrinogen. Porphyrinogenes (reduced porphyrins) formed during heme biosynthesis are easily oxidized (e.g. by light) to the corresponding porphyrins. The porphyrogenic effect of xenobiotics is also evidenced by the changes in proportions of selected porphyrins (porphyrins profile) in liver and urine [24,35].

Commercial preparations of OctaBDE available in the market before 2004 (known as: Bromkal 79-8 DE, DE-79 ${ }^{\mathrm{TM}}$, Tardex 80 , Saytex 111) were a mixture of different polybrominated diphenyl ethers. They usually comprised from $42 \%$ to $58 \%$ heptabromodiphenyl ethers, up to $12 \%$ penta- and hexa-, 26-36\% octa-, 8-14\% nona- and up to $2.1 \%$ of decabromodiphenyl ethers. The content of bromine in OctaBDE commercial mixture was $79 \%$. A range of isomers are found in OctaBDE that are described in the literature as congener numbers 194-205. The most common commercial mixtures of OctaBDE are BDE-196, BDE-197 and BDE-203 [1]. The studies referenced by the literature regarding the toxicity of OctaBDE were conducted by the producers of the commercial compound: the Great Lakes Chemical Corporation and Ethyl Corporation. Although in these products, OctaBDE represented only about $1 / 3$ of the 
total composition, the present study evaluated the mixture itself, which has roughly twice the OctaBDE content (about $2 / 3$ of the total composition).

The aim of the study was to assess the impact of OctaBDE on heme biosynthesis, through observing changes in ALA-S and ALA-D activity in the liver. Increases in ALA-S activity were observed most often, suggesting increased formation of the porphyrin precursor, delta-aminolevulinic acid. Lower ALA-S activity was noted only after the highest dose of OctaBDE had been administered for 21 and 28 days. Hence, heme would appear to act as a negative regulator of ALA-S synthesis, probably by means of the apopresor molecule. It is likely that at this stage the synthesis also takes place through feedback inhibition. The main effect of regulating the heme lies in the fact that the rate of ALA synthesis significantly increased in the absence of heme, and decreases in its presence [33]. A pronounced decrease in ALA-D activity in the livers of rats that received OctaBDE may indicate the occurrence of porphyria associated with the deficit of this enzyme (ALADP - ALA Dehydratase Deficiency Porphyria) $[34,35]$.

The adverse effects of OctaBDE on the transformations of porphyrins was also indicated by increased concentrations of high carboxylated porphyrins in the liver, where the presence of octacarboxyporphyrins (uroporphyrins) was predominant. Repeated administration of OctaBDE increased not only the concentrations of porphyrins in urine, but also their excretion with urine. Increased quantities of octa- and tetracarboxyporphyrins were evidenced in the rats' urine. The administration of OctaBDE also contributed to a pronounced augmentation of tetracarboxyporphyrin (coproporphyrin) concentration. In the overall quantity of porphyrins, the percentage of tetracarboxyporphyrins increased, whereas the percentage of octacarboxyporphyrin decreased. Changes in the profile of porphyrins with varying degrees of carboxylation also confirm the porphyrogenic activity of OctaBDE. Similar effects were noted during experiments where other brominated flame retardants (HBB, TBBP-A and PentaBDE) were examined [22-25,37].

In a previous experiment during which the porphyrogenic effect of PentaBDE was assessed, some specific changes in the appearance of the rats were noted, evidenced in particular by changes in their hair colour: a possible result of hypersensitivity to light, which is a frequent symptom of porphyria. The yellow (sometimes even orange) colour of the urine of rats exposed to PentaBDE could be caused by disorders in heme catabolism [25,38]. However, after repeated administration of OctaBDE, such clearly pronounced changes in the appearance were not observed, and changes in hair colour and urine were observed only after two highest doses: light brown colour around the snout, nose and anus and dark yellow (but not orange) urine.

Based on the research performed so far, it can be concluded that the studied brominated flame retardants show a porphyrogenic effect with varying intensity. Based on the total porphyrin concentrations in urine after a 4-week exposure of rats at $0.75 \%$ of the approximate lethal dose (ALD), that is, $40 \mathrm{mg} / \mathrm{kg} / \mathrm{day}$ for OctaBDE, the most porphyrogenic was found to be PentaBDE, followed by OctaBDE, while HBB and TBBP-A appeared to be least porphyrogenic [23-25].

The assessment of human exposure to PBDEs such as OctaBDE is most frequently based on measuring the concentrations of these compounds in biological material. Serum, adipose tissue and breast milk have most frequently been used for the analysis [1,18]. In the 1970s, research was conducted by one of the producers of the commercial OctaBDE formulation, the Great Lakes Chemical Corporation, assessing the levels of bromine in the tissues [1].

The results of this study may reassess the impact of human exposure to OctaBDE through the monitoring of the effects of the toxic compound. Such effects include, for instance, disorders in heme biosynthesis manifested 
by the increased excretion of porphyrins in urine. Similar effects were observed in 1973 after the Michigan accident in the USA. Polybromobisphenyls (PBBs) mistakenly administered with fodder caused the intoxication of breeding animals. Disturbances in heme synthesis such as coproporphyrinuria or chronic hepatic porphyria were also observed in humans consuming intoxicated food [21].

Based on the results of the study, it can also be noted that the lowest dose of OctaBDE used in the experiment ( $2 \mathrm{mg} / \mathrm{kg} /$ day) can be considered as the lowest effective dose. The increased concentrations of porphyrins in urine observed above that dose may become useful biomarkers of toxic effects. This effect can be useful to determine and/ or verify hygienic standards (TLV-TWA - threshold limit value-time weighed average; STEL - short-term exposure limit; ADI - acceptable daily intake; BEI - biological exposure indices) intended to prevent people from adverse effects of the compound.

\section{REFERENCES}

1. EU RAR. European Union, Risk Assessment Report. Diphenyl ether, octabromo derivative (octabromodiphenyl ether). 2003. CAS No. 32536-52-0, EINCES No. 251-087-9.

2. Directive 2003/11/EC of the European Parliament and of the Council of 6 February 2003 amending for the 24th time Council Directive 76/769/EEC relating to restrictions on the marketing and use of certain dangerous substances and preparations (pentabromodiphenyl ether and octabromodiphenyl ether). Off J EU L 42/45 (Feb 15, 2003).

3. Kemmlein S, Herzke D, Law RJ. Brominated flame retardants in the European chemicals policy of REACH-Regulation and determination in materials. J Chromatog A 2009;1216:320-33.

4. Gauthier LT, Hebert CE, Weseloh DVC, Letcher RJ. Dramatic changes in the temporal trends of polybrominated diphenyl ethers (PBDEs) in herring gull eggs from the Laurentian Great Lakes: 1982-2006. Environ Sci Technol 2008;42(5):1524-30.
5. Kohler M, Zennegg M, Bogdal C, Gerecke AC, Schmid P, Heeb NV, et al. Temporal trends, congener patterns, and sources of octa-, nona-, and decabromodiphenyl ethers (PBDE) and haxabromocyclododecanes $(H B C D)$ in Swiss lake sediments. Environ Sci Technol 2008;42(17):6378-84.

6. Yogui GT, Sericano JL. Polybrominated diphenyl ether flame retardants in the U.S. marine environment: a review. Environ Int 2009;35(3):655-66.

7. Antignac JP, Cariou R, Zalko D, Berrebi A, Cravedi JP, Maume D, et al. Exposure assessment of French women and their newborn to brominated flame retardants: determination of tri- to deca- polybromodiphenylethers (PBDE) in maternal adipose tissue, serum, breast milk and cord serum. Environ Pollut 2009;157(1):164-73.

8. Gill U, Chu I, Ryan JJ, Feeley M. Polybrominated diphenyl ethers: human tissue levels and toxicology. Rev Environ Contam Toxicol 2004;183:55-97.

9. Yu Z, Zheng K, Ren G, Zheng Y, Ma S, Peng P, et al. Identification of hydroxylated octa- and nona-bromodiphenyl ethers in human serum from electronic waste dismantling workers. Environ Sci Technol 2010;44(10):3979-85.

10. Zhang Y, Guo GC, Han X, Zhu C, Kilfoy BA, Zhu Y, et al. Do polybrominated diphenyl ethers (PBDEs) increase the risk of thyroid cancer? Biosci Hypotheses 2008;1(4):195-9.

11. Jakobsson K, Thuresson K, Rylander L, Sjödin A, Hagmar L, Bergman A. Exposure to polybrominated diphenyl ethers and tetrabromobisphenol A among computer technicians. Chemosphere 2002;46(5):709-16.

12. Thuresson K, Bergman K, Rothenbacher K, Herrmenn T, Sjödin S, Hagmar L, et al. Polybrominated diphenyl ether exposure to electronics recycling workers - A follow up study. Chemosphere 2006a;64(11):1855-61.

13. Thuresson K, Höglund P, Hagmar L, Sjödin S, Bergman A, Jakobsson K. Apparent half-lives of hepta- to decabrominated diphenyl ethers in human serum as determined in occupationally exposed workers. Environ Health Perspect 2006;114(2):176-81. 
14. Pettersson-Julander A, van Bavel B, Engwall M, Westberg H. Personal air sampling and analysis of polybrominated diphenyl ethers and other bromine containing compounds at an electronic recycling facility in Sweden. J Environ Monit 2004(11);6:874-80.

15. Ying Z, Song J, He Z, Yuan H, Xu Y. Toxic octabromodiphenyl ether is being transported from rich to poor via electronic waste. Ambio 2009;38(2):115-7.

16. Takigami H, Suzuki G, Hirai Y, Sakai SI. Brominated flame retardants and other polyhalogenated compounds in indoor air and dust from two houses in Japan. Chemosphere 2009;76(2):270-77.

17. Chao HR, Shy CG, Wang SL, Chen SCC, Koh TW, Chen FA, et al. Impact of non-occupational exposure to polybrominated diphenyl ethers on menstruation characteristics of reproductive-age females. Environ Int 2010;36(7):728-35.

18. Costa LG, Giordano G, Tagliaferri S, Caglieri A, Mutti A. Polybrominated diphenyl ether (PBDE) flame retardants: environmental contamination, human body burden and potential adverse health effects. Acta Biomed 2008;79(3):172-83.

19. Talsness CE. Overview of toxicological aspects of polybrominated diphenyl ethers: A flame-retardant additive in several consumer products. Environ Res 2008;108(2):158-67.

20. Viberg H, Johansson N, Fredriksson A, Eriksson J, Marsh G, Eriksson P. Neonatal exposure to higher brominated diphenyl ethers, hepta-, octa-, or nonabromodiphenyl ether, impairs spontaneous behavior and learning and memory functions of adult mice. Toxicol Sci 2006;92(1):211-8.

21. EHC. Environmental Health Criteria 152. Polybrominated biphenyls. International Programme on Chemical Safety (IPCS). Geneva: WHO; 1994.

22. Frydrych B, Szymańska JA, Świderska-Comer A. Concentration of porphyrins in rat liver and kidneys after repeated administration of hexabromobenzene and tetrabromobisphenol-A. Pol J Environ Stud 2006;15(4):543-8.

23. Szymańska JA, Piotrowski JK, Frydrych B. Hepatotoxicity of tetrabromobisphenol-A: effects of repeated dosage in rats. Toxicology 2000;142(2):87-95.
24. Szymańska JA, Piotrowski JK. Hepatotoxicity of monobromobenzene and hexabromobenzene: effects of repeated dosage in rats. Chemosphere 2000;41(10):1689-96.

25. Bruchajzer E. Porphyrogenic effect of pentabromodiphenyl ether after repeated administration to rats. Arch Toxicol 2011;85(8):965-74.

26. EHC. Environmental Health Criteria 162. Brominated diphenyl ethers. International Programme on Chemical Safety (IPCS). Geneva: WHO; 1994.

27. Luo J, Lim CK. Isolation and characterization of new porphyrin metabolites in human porphyria cutanea tarda and in rats treated with hexachlorobenzene by HPTLC, HPLC and liquid secondary ion mass spectrometry. Biomed Chromatogr 1995;9(3):113-22.

28. Lim CK, Peters T. Urine and faecal porphyrin profiles by reversed phase high-performance liquid chromatography in the porphyries. Clin Chim Acta 1984;139(1):55-63.

29. Sassa S, Granick S. Induction of $\delta$-aminolevulinic acid synthetase in chick embryo liver cells in culture. Proc Natl Acad Sci USA 1970;67(2):517-22.

30. Berlin A, Schaller KH. European standardized method for the determination of delta-aminolevulinic acid dehydratase activity in blood. Z Klin Chem Biochem 1974;12(8):189-90.

31. Schlick E, Mengel K, Friedberg KD. The effect of low lead doses in vitro and in vivo on the d-ala-d activity of erythrocytes, bone marrow cells, liver and brain of the mouse. Arch Toxicol 1983;53(3):193-205.

32. Law on animal experiments. J Law 2005 No. 33, item 289 (Jan 21, 2005) [in Polish].

33. Ajioka RS, Phillips JD, Kushner JP. Biosynthesis of heme in mammals. Biochim Biophys Acta 2006;1763(7):723-36.

34. Poblete-Gutierrez P, Wiederholt T, Merk HF, Frank J. The porphyrias: clinical presentation, diagnosis and treatment. Eur J Dermatol 2006;16(3):230-40.

35. Sassa S. Modern diagnosis and management of the porphyries. Br J Haematol 2006;135(3):281-92.

36. Thunell S, Pomp E, Brun A. Guide to drug porphyrogenicity prediction and drug prescription in the acute porphyries. Br J Clin Pharmacol 2007;64(5):668-79. 
37. EU RAR (2001). European Union, Risk Assessment Report. Diphenyl ether, pentabromo derivative (pentabromodiphenyl ether). CAS No.: 32534-81-9, EINCES No. 251-084-2.

38. Niittynen M, Toumisto JT, Pohjanvirta R. Effect of 2,3,7,8-tetrachlorodibenzo-p-dioxin (TCDD) on heme oxygenase-1, biliverdin IXa reductase and $\delta$-aminolevulinic acid synthetase 1 in rats with wild-type or variant AH receptor. Toxicology 2008;250(2-3):132-42.

This work is available in Open Access model and licensed under a Creative Commons Attribution-NonCommercial 3.0 Poland License - http://creativecommons.org/ licenses/by-nc/3.0/pl/deed.en. 